\title{
FEATURE Economic dimensions of soil health practices that sequester carbon: Promising research directions
}

Roderick M. Rejesus, Serkan Aglasan, Lynn G. Knight, Michel A. Cavigelli, Curtis J. Dell, Erin D. Lane, and David Y. Hollinger

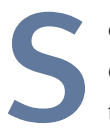
oil health is a key element in enhancing agricultural production, environmental sustainability, and food system resilience (Farnsworth 2015; Stevens 2018). The USDA Natural Resources Conservation Service (NRCS) defines soil health as "the continued capacity of soil to function as a vital living ecosystem that sustains plants, animals, and humans" (Pankhurst et al. 1997; Farnsworth 2015; Bowman et al. 2016). A common theme points to soil health as an indicator of the soil's ability to support life, withstand environmental stresses, and endure as an important part of a resilient ecosystem. Because one of the key individual components of soil health is carbon (C) in organic matter (Idowu et al. 2009; Morrow et al. 2016), enhancing soil health also has a prominent role to play in addressing climate change (Stockmann et al. 2013; Schipanski et al. 2014; Paustian et al. 2016). Improving soil health is a natural climate solution (NCS) that increases $\mathrm{C}$ storage in soils (Poeplau and Don 2015; Griscom et al. 2017; Jian et al. 2020).

Given soil health's key role in sustaining agricultural productivity and enhancing $\mathrm{C}$ storage, there is significant interest in promoting agricultural management decisions, practices, and production systems that can help maintain or improve soil health. These include practices such as cover cropping, no-till residue and tillage management, conservation crop rotations, mulching, and nutrient management. However, adoption of these soil health practices by farmers is inextricably linked to whether private economic benefits from implementing these practices (i.e., benefits to the farmer) outweigh the associated private adoption costs. In addition, understanding the environmental benefits from adopting these soil health practices (i.e., external benefits to society through ecosystems services) can help inform design of public policies seeking to align private incentives with public envi- ronmental goals (for example, designing of subsidy payments to farmers).

In this paper, we describe the economic dimensions associated with the decision to adopt soil health practices. These are important concepts that will help soil and water conservation practitioners further encourage adoption of soil health practices. Here, we summarize recent literature that examines the economic benefits and costs of cover crops and no-till systems for the United States, in general, and the understudied Northeast region of the United States, in particular. The Northeast is chosen here because several states in this region (i.e., Maryland, Pennsylvania, Delaware) are among the top states in terms of percentage cover crop and no-till adoption (Zulauf and Brown 2019a, 2019b). Yet there have been few economic studies of soil health practices for this region (more on this below). The Northeast region of the United States in this study includes Connecticut, Delaware, Maine, Maryland, Massachusetts, New Hampshire, New Jersey, New York, Pennsylvania, Rhode Island, and Vermont. Adoption of cover crops and no-till varies widely across the United States (figure 1). Key research directions are identified that would enhance understanding of the economics of soil health practices and provide insights into policies that can help encourage adoption of these C-sequestering soil health practices.

\section{SOIL HEALTH PRACTICES THROUGH AN ECONOMIC LENS}

Economic considerations are one of the main elements that an individual farmer typically assesses when making decisions to adopt soil health management practices. Therefore, it is important to provide an economic framework as a lens for understanding how one assesses the various factors influencing the decision to adopt soil health practices and how one evaluates the overall economic impacts of these practices.
Building on the "ecosystem-centered" NRCS definition of soil health, our economic framework conceptualizes soil health as encompassing the physical, chemical, and biological characteristics of the soil, therefore not simply equating soil health to soil fertility (Stevens 2018). Three key factors-initial soil conditions, agricultural management practices, and environmental conditions-interact and eventually influence soil health (figure 2). Of these three key factors, only agricultural management practices are directly under the control of the farmer. Moreover, specific adoption of agricultural management practices that influence soil health depends on the economic benefits and costs associated with using these practices. Soil health is also linked to environmental outcomes that society values (e.g., reduced soil erosion, reduced nitrogen [N] and phosphorus $[\mathrm{P}]$ runoff to water bodies, and sequestration of atmospheric $\mathrm{C}$ in the soil from use of cover crops [Poeplau and Don 2015; Jian et al. 2020]). Hence, an important dimension when thinking about the economics of soil health is delineating between private versus external (or societal) benefits and costs (table 1). In terms of soil health practices, farmers typically bear all the cost of adoption (when cost-share subsidies are not considered), but benefits are received by both the farmer and society. This "mismatch" in terms of who receives benefits and who bears the costs suggests that there may be

Roderick M. Rejesus (corresponding author) is a professor and extension specialist at North Carolina State University, Raleigh, North Carolina. Serkan Aglasan is a postdoctoral associate at North Carolina State University, Raleigh, North Carolina. Lynn G. Knight is an economist at the East National Technology Support Center, USDA Natural Resources Conservation Service, Milton, Vermont. Michel A. Cavigelli is a research soil scientist at the USDA Agricultural Research Service, Beltsville, Maryland. Curtis J. Dell is a research soil scientist at the USDA Agricultural Research Service, University Park, Pennsylvania. Erin D. Lane is coordinator and David Y. Hollinger is director at the USDA Northeast Climate Hub, Durham, New Hampshire. 
"underprovision" of soil health benefits from the adoption of soil health-enhancing practices. Since farmers bear all the cost, they will only adopt soil health practices commensurate to the direct benefits they receive without typically considering the environmental benefits to society. This potential market failure suggests a likely role for public policy in terms of helping farmers "internalize" the external benefits of soil health practices, by designing interventions (e.g., subsidies) for optimal societal provision of soil health benefits (Stevens 2018).

Another important dimension in the economics of soil health is the inherently dynamic nature of economic outcomes that arise from adoption of soil health management practices. That is, the action to adopt a soil health management practice influences economic outcomes during the period of adoption, as well as in future periods. The management practice effects in each future period are governed by evolving climatic, environmental, and soil conditions, and the natural process by which soil health responds to each management practice. Therefore, economic outcomes from adoption of soil health management practices dynamically evolve and likely accumulate depending on the number of years the particular management practices are used (Myers et al. 2019).Variability of economic outcomes over time (e.g., yield stability or yield risk) is then also a factor when considering the economics of soil health management practices (Boyer et al. 2018; Stevens 2018). Whether soil health practices reduce variability in yields and revenues over time is a pertinent economic question given the dynamics.

\section{WHAT HAVE WE LEARNED FROM THE ECONOMIC LITERATURE ON SOIL HEALTH PRACTICES?}

Much of the literature that examines the economics of soil health practices in the United States focuses on the private benefits and costs associated with adopting a particular soil health practice. Long-term studies that account for the dynamics and external dimensions of soil health management practices have been limited. For cover crops, the recent economic literature has mainly used partial budget analysis and

\section{Figure 1}

(a) Cover crop acres and (b) no-till acres as a percentage of state total crop acres in the United States based on the 2017 US Census of Agriculture.

(a)

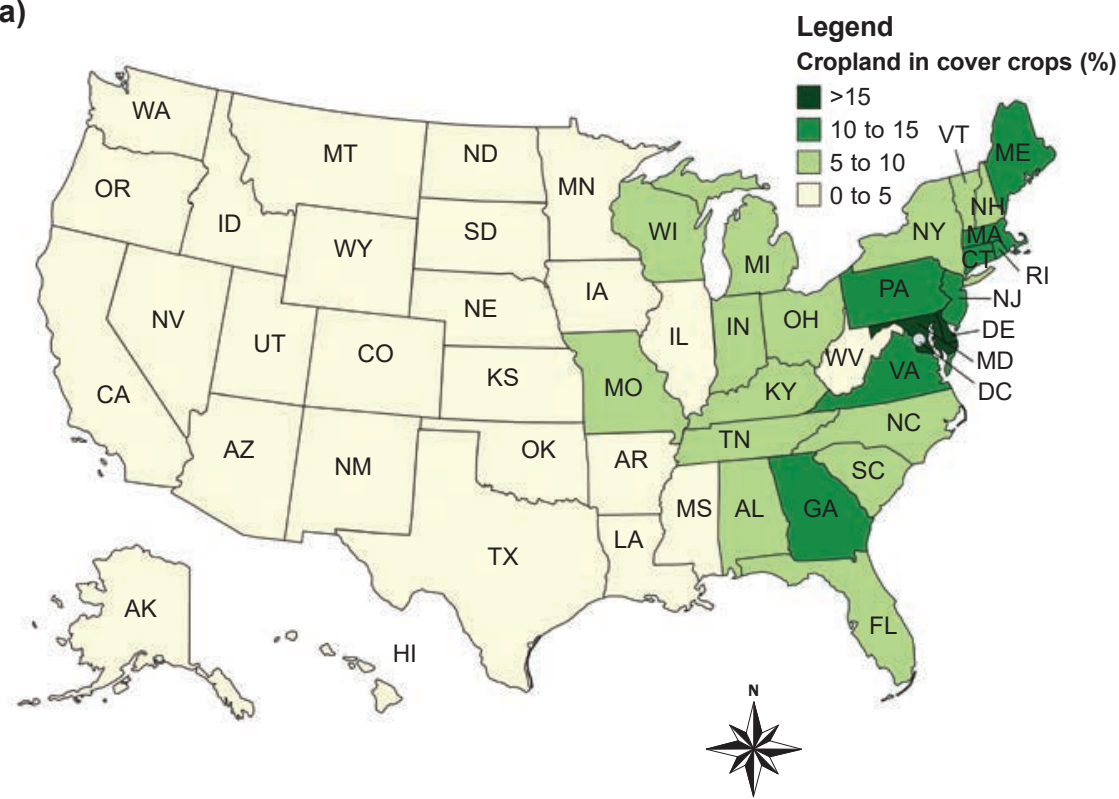

(b)

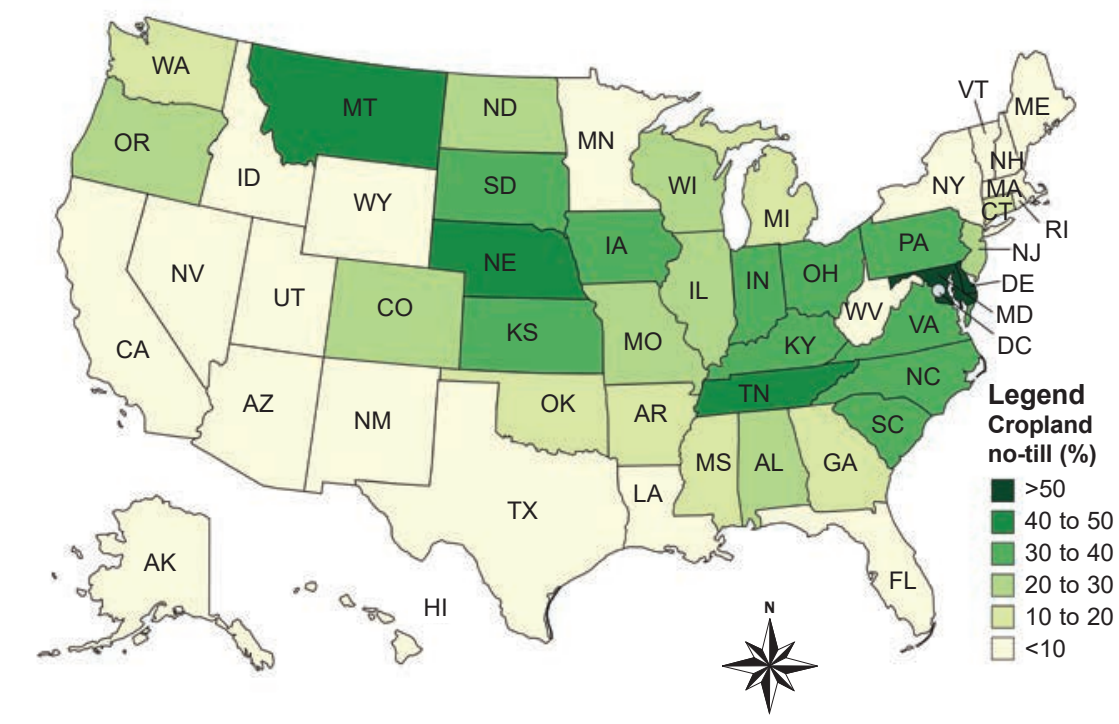

generally finds that short-term (i.e., one year), private benefits from adoption of cover crops typically are not higher than the initial costs of implementation (Myers et al. 2019; Plastina et al. 2018a, 2018b, 2020). This lack of short-term private net benefit to growers is often seen as a major factor for the low ( 4\%) cover crop adoption in the United States (Zulauf and Brown 2019a) (figure 1a). Long-term use of cover crops is likely needed for farm- ers to receive positive net economic returns (Myers et al. 2019; Boyer et al. 2018). Moreover, an aspect of cover crop economics that has not been thoroughly investigated is the economic value associated with the potential external benefits of cover crop use (Bergtold et al. 2017).

For no-till systems, the economic literature indicates that private net economic benefits from adoption are variable and site-specific. That is, private benefits 


\section{Figure 2}

Feedbacks from analysis of the economics of soil health practices. Analyzing the impact of management practices could improve understanding of policies for encouraging best soil management practices. Use of these best management activities can improve soil conditions (relative to some benchmark) and may lead to improved private economic benefits and public environmental benefits, such as carbon sequestration (see table 1). Further enhancements and analysis of the benefits of soil health practices then create feedback loops.

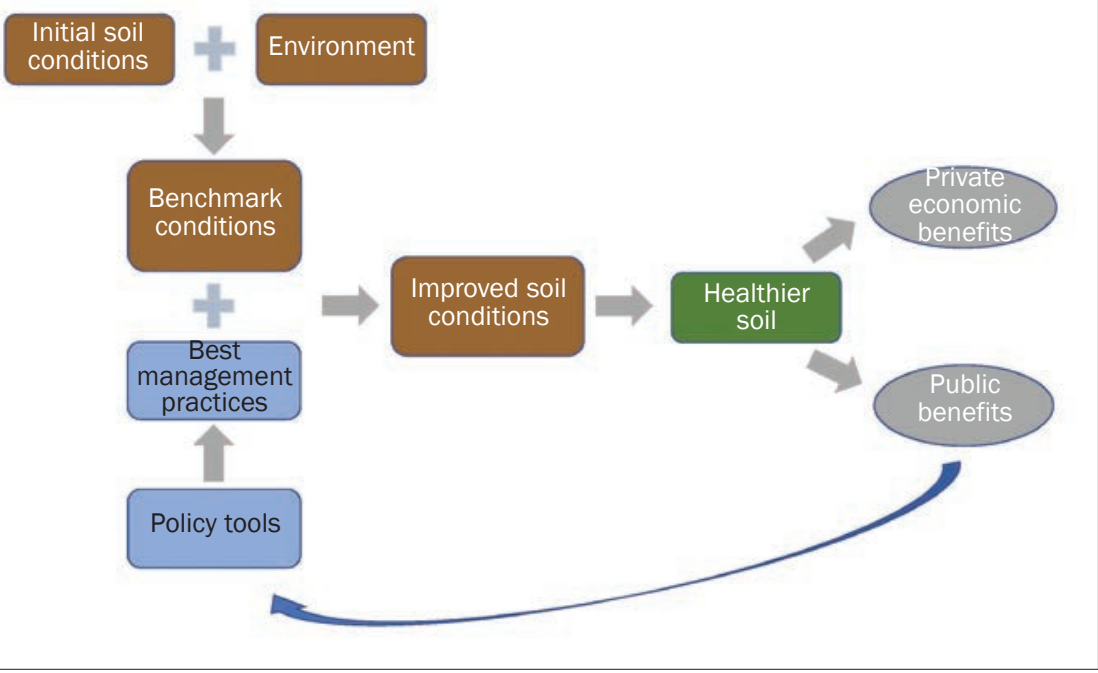

and costs depend on factors such as soil characteristics, local climatic conditions, cropping patterns, and other attributes of the overall farming operation (Toliver et al. 2012; Ding et al. 2009; Cusser et al. 2020). However, the observed increase in no-till adoption rates over the last few decades ( $~ 37 \%$ of US cropland area) suggests that farmers are adopting these no-till systems, and implies that these systems generally pay off for US farmers (Zulauf and Brown 2019b) (figure 1b).

The economics literature focusing on soil health practices in the US Northeast follows the main trends found in the United States in general. However, many of the economic studies of cover cropping and no-till systems in this region were conducted prior to 2010 using budgeting type approaches (Hanson et al. 1993; Lichtenberg et al. 1994; Cavigelli et al. 2009; White et al. 2019). Aside from these budget-based analyses (usually using plotlevel experimental data), economic studies in this region have also used biophysicaleconomic simulation models to examine long-term soil, environmental, and economic outcomes (Lu et al. 2000; Watkins et al. 2002). These studies have generally shown favorable economic and environ- mental outcomes from long-term use of cover crops or no-till systems. Note, however, that most of the soil health-related studies in the region have focused on the effects of cover crops or no-till systems on environmental, agronomic, and soil health outcomes, rather than economic outcomes per se. Moreover, these cover cropping and no-till economic studies were conducted in Maryland, New York, and Pennsylvania, with limited research in other Northeast states. Notwithstanding the limited economic studies in this region, a number of Northeast states rank among the top in terms of adoption of cover cropping and no-till systems based on the 2017 US Census of Agriculture (Zulauf and Brown 2019a, 2019b) (figure 1). Maryland and Delaware lead the nation in both cover crop and no-till adoption percentages, with 8 of the top 10 cover crop states in the Northeast (figure 1).

An important strand of economic literature that has been conducted mostly in the Northeast (Maryland in particular) is one that investigates how cost-share payments affect adoption of soil health practices like cover crops and conservation tillage (Fleming 2017; Fleming et al. 2018; Lichtenberg et al. 2018). These studies spe- cifically look at "additionality" provided by these programs, where additionality is defined as the adoption of conservation practices that would not have occurred in the absence of cost-share payments. These studies typically find strong, direct additionality (where cost-share payments increase cover crop acreage) and sometimes they also find indirect additionality (where costshare payments also encourage adoption of other conservation practices). Maryland and Delaware have long-standing statefunded cost-share programs, in addition to the federal conservation programs, that have most likely helped encourage adoption of cover crops and no-till systems in these states. These studies highlight the importance of analyzing conservation payment programs to determine how effective their designs are in encouraging adoption of conservation practices like cover crops and no-till systems.

\section{PROMISING RESEARCH DIRECTIONS IN} THE ECONOMICS OF SOIL HEALTH

Given the current state of the soil health economic literature, more long-term economic studies are needed to estimate the causal relationships among soil health practices, soil health indicators, and economic outcomes using longitudinal data sets and rigorous statistical techniques (Cusser et al. 2020). Dynamic issues associated with cover crops and no-till (e.g., risk impacts and investment analysis under uncertainty) are also topics that need further study. Geographical heterogeneity of soils and agricultural production systems also needs to be recognized, and economic evaluations of cover crop or no-till use will likely need to be conducted for different regions. Successful implementation of longer-term evaluations may require interdisciplinary collaborations among economists, soil conservation experts, agronomists, and/ or other scientists. It is critical that economists responsible for assessing economic impacts are intimately involved at the start of the conceptualization and development of the long-term evaluation of soil health practices. Having economists involved at the onset will allow for more pointed long-term field-level evaluations of the soil health conservation strategies to determine whether these practices meet private prof- 


\section{Table 1}

Economic dimensions of soil health management practice decisions.

\begin{tabular}{|c|c|c|}
\hline Type & Potential benefits (revenue increasing or cost decreasing) & Potential costs (revenue decreasing or cost increasing) \\
\hline $\begin{array}{l}\text { Private } \\
\text { (e.g., individual) }\end{array}$ & $\begin{array}{l}\text { Agronomic: } \\
\text { - Increased yields (and revenues) } \\
\text { - Reduced fertilizer expenses } \\
\text { - Reduced fuel cost (in no-till) } \\
\text { - Better resilience to extreme weather events } \\
\text { - Yield stability over time } \\
\text { - Grazing opportunities (from cover crops) } \\
\text { Environmental: } \\
\text { - Reduced soil erosion in farmer fields } \\
\text { - Decreased soil compaction } \\
\text { - Reduced nitrogen and phosphorus losses increasing } \\
\text { - nutrient use efficiency } \\
\text { - Better moisture retention in-season }\end{array}$ & $\begin{array}{l}\text { Agronomic: } \\
\text { - Increased cover crop seed costs } \\
\text { - Increased labor and machinery cost (e.g., for planting } \\
\text { cover crops) } \\
\text { - Increased herbicide costs (e.g., for cover crop termination } \\
\text { and weeds in no-till systems) } \\
\text { - Decreased yield (e.g., if delayed planting due to delayed } \\
\text { cover crop termination, among other reasons) } \\
\text { - Opportunity cost of labor for planting cover crops in the winter } \\
\text { - Decreased moisture available for cash crop (after planting } \\
\text { cover crops) } \\
\text { - May recruit unwanted wildlife (for cover crops) } \\
\text { Environmental: } \\
\text { - None }\end{array}$ \\
\hline $\begin{array}{l}\text { External } \\
\text { (e.g., societal) }\end{array}$ & $\begin{array}{l}\text { Agronomic: } \\
\text { - Reduced pest and disease outbreak incidence (e.g., due } \\
\text { to beneficial insects) } \\
\text { Environmental: } \\
\text { - Reduced soil erosion on landscape } \\
\text { - Carbon sequestration (e.g., cover crops or no-till remove } \\
\text { carbon dioxide from the air and store it in the form of carbon } \\
\text { in the plant and/or soil) } \\
\text { - Improved water quality (e.g., from reduced nitrate leaching) } \\
\text { - Increased biodiversity (e.g., better environment for beneficial } \\
\text { insects and pollinators) }\end{array}$ & $\begin{array}{l}\text { Agronomic: } \\
\text { - Increased pest or disease incidence for neighbors due to } \\
\text { cover crops being a possible host } \\
\text { Environmental: } \\
\text { - None } \\
\end{array}$ \\
\hline
\end{tabular}

itability and societal environmental benefit thresholds for sustained adoption.

In addition, use of more aggregate data sets, such as county-level, satellite-based data, needs to be explored as this can allow further study of a variety of economic issues (e.g., risk and dynamics) over a longer period of time and covering a wider geographical scale, which plot-level experimental data usually do not adequately address. Collection of observational farmlevel data (rather than experimental data) on soil health practice adoption is important to also ascertain how these practices influence economic outcomes on the farm. Factors affecting so-called "yield gaps" between field experimental outcomes and on-farm economic outcomes can be identified when using information from farm adopters and nonadopters of these soil health practices (van Ittersum et al. 2013). The yearly farm survey data collected by the USDA National Agricultural
Statistics Service (e.g., the Agricultural Resource Management Survey and the US Census of Agriculture) continue to be essential for understanding the long-term economic and environmental outcomes of these $\mathrm{C}$ sequestering soil health practices.

Use of nonmarket valuation techniques to estimate the societal external contributions (i.e., the ecosystem services) of soil health practices is another research avenue that is likely to be fruitful (Bergtold et al. 2017). These types of studies can advance understanding of how cover crops, notill systems, and other soil health building practices influence environmental outcomes (e.g., amount of $\mathrm{C}$ sequestered or $\mathrm{N}$ leaching avoided), and allow one to attach a value to these societal benefits (i.e., provide an economic value to the $\mathrm{C}$ sequestration benefit), even if it is not a perfect estimate. Recognizing the value of these external benefits makes it possible to more accurately ascertain the total net benefits of these soil health conservation practices, and may help provide justification, as well as guidance, for developing conservation payment programs that encourage further adoption.

Overall, economic studies based on long-term data, especially those that incorporate dynamics and value external benefits, would provide a more holistic picture of the economic potential of adopting soil health management practices. These kinds of studies would give more meaningful information as compared to the simpler approach of showing private economic outcomes from short-term use of a practice. Demonstrating strong economic outcomes over time would likely encourage further adoption of these soil health practices and will likely result in more $\mathrm{C}$ sequestration to help address the climate change challenge society faces.

Last, further examination of the role and design of different conservation payment 
programs can inform development of public policies that aim to further incentivize the adoption of soil health practices and $\mathrm{C}$ sequestration. There are studies that have investigated the effectiveness of costshare payment programs by examining whether these programs induce a positive change in the adoption of conservation practices, such as cover crops (Mezzatesta et al. 2013; Fleming 2017; Claassen et al. 2018). However, these studies typically have not separately investigated the effects of different cost-share programs (i.e., all payments from federal, state, and local sources are lumped together), or only the adoption effects of one specific payment program were examined. Studies that explore how different cost-share payment programs affect adoption of specific soil health practices, as well as the effects on disadoption after payments end, would be fruitful future research directions. For example, research that looks at the adoption effects of government cost-share programs (like the Environmental Quality Incentives Program and the Conservation Stewardship Program) vis-à-vis the state level conservation payment programs (like the Maryland Agricultural and Water Quality Cost Sharing program) would provide important insights as to which cost-share payment structure or design is more effective in encouraging adoption of soil health practices and result in more permanent use even without the cost-share. Moreover, how these conservation payment programs interact with other government-supported safety net programs (e.g., the commodity programs from the farm bill, crop insurance, etc.) and affect soil health adoption decisions needs to be studied further as well (Schoengold et al. 2015). Separately, investigating the impact of private $\mathrm{C}$ market payments that encourage soil health practice adoption and the state-level programs that utilize crop insurance premium discounts to incentivize adoption of soil health are promising future research avenues that can inform design of more effective conservation payment programs.

The value of reducing climate change impacts to society is immense. Pursuing the research directions described above is an important step for understanding how the agricultural sector can contribute to achieving this goal. Investigating adoption of soil health practices through an economic lens provides critical information that can further incentivize the use of these $\mathrm{C}$ sequestering approaches.

\section{ACKNOWLEDGEMENTS}

The authors gratefully acknowledge support from USDA Agreement Numbers NRC19IRA0010111 and FS19JV11242306-117. The work of Rejesus was also supported in part by USDA National Institute of Food and Agriculture Hatch Project No. NC02696. Figure 1 in the document was created via mapchart and licensed under a Creative Commons AttributionShareAlike 4.0 International License.This research was a contribution from the Long-Term Agroecosystem Research (LTAR) network. LTAR is supported by the USDA, which is an equal opportunity provider and employer. The findings and conclusions in this publication are those of the authors and should not be construed to represent any official USDA or US Government determination or policy.

\section{REFERENCES}

Bergtold, J.S., S. Ramsey, L. Maddy, and J.R. Williams. 2017. A review of economic considerations for cover crops as a conservation practice. Renewable Agriculture and Food Systems 34:62-76.

Bowman, M., S. Wallander, and L. Lynch. 2016. An economic perspective on soil health. Amber Waves. Economic Research Service Publication. Washington, DC: Economic Research Service.

Boyer, C.N., D.M. Lambert, J.A. Larson, and D.D. Tyler. 2018. Investment analysis of cover crop and no-tillage systems in Tennessee cotton. Agronomy Journal 111:331-338.

Cavigelli, M.A., B.L. Hima, J.C. Hanson, J.R.Teasdale, A.E. Conklin, and Y. Lu. 2009. Long-term economic performance of organic and conventional field crops in the Mid-Atlantic region. Renewable Agriculture and Food Systems 24:102-119.

Claassen, R., E.N. Duquette, and D.J. Smith. 2018 Additionality in U.S. agricultural conservation programs. Land Economics 94(1):19-35.

Cusser, S., C. Bahlai, S.M. Swinton, G.P. Robertson, and N.M. Haddad. 2020. Long-term research avoids spurious and misleading trends in sustainability attributes of no-till. Global Change Biology 26:3715-3725.

Ding, Y., K. Schoengold, and T. Tadesse. 2009. The impact of weather extremes on agricultural production methods: Does drought increase adoption of conservation tillage practices?
Journal of Agricultural and Resource Economics 34(3):395-411.

Farnsworth, R. 2015. Economics of soil health: a selected review and assessment of the existing literature. Paper presented at the Economics of Soil Health Conference, Washington, DC, September 21-22, 2015.

Fleming, P. 2017. Agricultural cost sharing and water quality in the Chesapeake Bay: Estimating indirect effects of environmental payments. American Journal of Agricultural Economics 99:1208-1227.

Fleming, P., E. Lichtenberg, and D.A. Newburn. 2018. Evaluating impacts of agricultural cost sharing on water quality: Additionality, crowding in, and slippage. Journal of Environmental Economics and Management 92:1-19.

Griscom, B.W., J. Adams, P.W. Ellis, R.A. Houghton, G. Lomax, D.A. Miteva, W.H. Schlesinger, D. Shoch, J.V. Siikamäki, P. Smith, and P. Woodbury. 2017. Natural climate solutions. Proceedings of the National Academy of Sciences 114(44):11645-11650.

Hanson, J.C., E. Lichtenberg, A.M. Decker, and A.J. Clark. 1993. Profitability of no-tillage corn following a hairy vetch cover crop. Journal of Production Agriculture 6:432-437.

Idowu, O.J., H.M. van Es, G.S. Abawi, D.W. Wolfe, R.R. Schindelbeck, B.N. Moebius-Clune, and B.K. Gugino. 2009. Use of an integrative soil health test for evaluation of soil management impacts. Renewable Agriculture and Food Systems 24:214-224

Jian, J., X. Du, M.S. Reiter, and R.D. Stewart. 2020. A meta-analysis of global cropland soil carbon changes due to cover cropping. Soil Biology and Biochemistry 143:107735.

Lichtenberg, E., J.C. Hanson, A.M. Decker, and A.J. Clark. 1994. Profitability of legume cover crops in the Mid-Atlantic region. Journal of Soil and Water Conservation 49(6):582-585.

Lichtenberg, E., H. Wang, and D.A. Newburn. 2018. Uptake and additionality in a green payment program: A panel data study of the Maryland cover crop program. Selected Paper, 2018 Agricultural and Applied Economics Association Annual Meeting, Washington, DC, August 5-7, 2018.

Lu, Y.C., B. Watkins, J.R. Teasdale, and A.A. AbdulBaki. 2000. Cover crops in sustainable food production. Food Reviews International 16:121-157.

Mezzatesta, M., D.A. Newburn, and R.T. Woodward. 2013. Additionality and the adoption of farm conservation practices. Land Economics 89(4):722-742. 
Morrow, J.G., D.R. Huggins, L.A. Carpenter-Boggs, and J.P. Reganold. 2016. Evaluating measures to assess soil health in long-term agroecoystem trials. Soil Science Society of America Journal 80:450-462.

Myers, R.,A.Weber, and S. Tellatin. 2019. Cover crop economics: Opportunities to improve your bottom line in row crops. SARE Technical Bulletin, Ag. Innovation Series.

Pankhurst, C., B.M. Doube, and V.V.S.R. Gupta, eds. 1997. Biological Indicators of Soil Health. Wallingford, UK: CAB International.

Paustian, K., J. Lehmann, S. Ogle, D. Reay, G.P. Robertson, and P. Smith. 2016. Climate-smart soils. Nature 532:49-57.

Plastina, A., F. Liu, F. Miguez, and S. Carlson. 2020. Cover crops use in Midwestern US agriculture: Perceived benefits and net returns. Renewable Agriculture and Food Systems 35:38-48.

Plastina, A., F. Liu, W. Sawadgo, F. Miguez, and S. Carlson. 2018a. Partial budgets for cover crops in Midwest row crop farming. Journal of the ASFMRA 90-106.

Plastina, A., F. Liu, W. Sawadgo, F. Miguez, S. Carlson, and G. Marcillo. 2018b. Annual net returns to cover crops in Iowa. Journal of Applied Farm Economics 2:19-36.

Poeplau, C., and A. Don. 2015. Carbon Sequestration in agricultural soils via cultivation of cover crops - A meta-analysis. Agriculture, Ecosystems, and Environment 200:33-41.

Schipanski, M.E., M. Barbercheck, M.R. Douglas, D.M. Finney, K. Haider, J.P. Kaye, A.R. Kemanian D.A. Mortensen, M.R. Ryan, J. Tooker, and C. White. 2014. A framework for evaluating ecosystem services provided by cover crops in agroecosystems. Agricultural Systems 125:12-22.

Schoengold, K., Y. Ding, and R. Headlee. 2015. The impact of ad hoc disaster and crop insurance pro- grams on the use of risk-reducing conservation tillage practices. American Journal of Agricultural Economics 97(3):897-919.

Stevens, A.W. 2018. Review: The economics of soil health. Food Policy 80:1-9.

Stockman, U., M.A. Adams, J.W. Crawford, D.J. Field, N. Henakaarchchi, M. Jenkins, B. Minasny, A.B. McBratney,V.D.R. de Courcelles, K. Singh, I. Wheeler, L. Abbott, D.A. Angers, J. Baldock, M. Bird, P.C. Brookes, C. Chenu, J.D. Jastrow, R. Lal, J. Lehmann, A.G. O’Donnell, W.J. Parton, D. Whitehead, and M. Zimmerman. 2013. The knowns, known unknowns, and unknowns of sequestration of soil organic carbon. Agriculture, Ecosystems and Environment 163:80-99.

Toliver, D.K., J.A. Larson, R.K., Roberts, B.C. English, D.G. De La Torre Ugarte, and T.O. West. 2012. Effects of no-till on yields as influenced by crop and environmental factors. Agronomy Journal 104:530-541.

Van Ittersum, M.K., K.G. Cassman, P. Grassini, and J. Wolf. 2013.Yield gap analysis with local to global relevance - A Review. Field Crops Research 143:4-17.

Watkins, K.B.,Y.C. Lu, and J.R. Teasdale. 2002. Longterm environmental and economic simulation of alternative cropping systems in Maryland. Journal of Sustainable Agriculture. 20:61-82.

White, K.E, M.A. Cavigelli, A.E. Conklin, and C. Rasmann. 2019. Economic performance of long-term organic and conventional crop rotations in the Mid-Atlantic. Agronomy Journal 111:1358-1370.

Zulauf, C., and B. Brown. 2019a. Cover crops, 2017 US census of agriculture. Farmdoc Daily 9(135):1-3.

Zulauf, C., and B. Brown. 2019b. Tillage Practices, 2017 US census of agriculture. Farmdoc Daily 9(136):1-5. 